\title{
Risky Sexual Behaviors and Associated Factors among Students of Mizan Aman College of Health Science, Southwest Ethiopia: Cross- Sectional Study
}

\author{
Teklemariam Ergat Yarinbab ${ }^{1 *}$, Nega Yimer Tawi² ${ }^{2}$ Israel Darkiab² ${ }^{2}$, Fikadu Debele ${ }^{2}$ and Wasihun Adraro
} $\mathrm{Ambo}^{2}$

${ }^{1}$ Department of Public Health, College of Health Science, Mizan-Tepi University, Ethiopia

${ }^{2}$ Department of Public Health, Mizan-Aman College of Health Science, Ethiopia

Submission: June 16, 2018; Published: June 22, 2018

*Corresponding author: Teklemariam Ergat Yarinbab, 1Department of Public Health, College of Health Science, Mizan-Tepi University, Ethiopia, Email: teklemariam36@gmail.com/teklemariam@mtu.edu.et

\begin{abstract}
Background: Risky sexual behavior is a behavior related to sexuality which increases the susceptibility of an individual to reproductive health problems like Sexually Transmitted Diseases (STIs), unwanted pregnancy, abortion and psychological distress. Young people's are at higher risk of practicing risky sexual behaviors due to their risk taking behavior. The rate of risky sexual behaviors is increasing in developing countries. Therefore, the aim of this study was to assess the risky sexual behaviors and associated factors among students of Mizan-Aman College of Health Science, Southwest Ethiopia.

Methods: Institution based cross sectional study was conducted in Mizan-Aman College of Health Science, Southwest Ethiopia. Simple random sampling technique was used. Data was collected using self-administered questionnaires. SPSS version 20.0 was used for Bivariate and Multivariate Analysis.

Result: About 35\% of the respondents had at least one of the risky sexual behaviors. Accordingly; $57.6 \%$ of the respondents reported to have sexual intercourse before age of eighteen, $16.3 \%$ had more than one sexual partner, $16.7 \%$ had sexual intercourse with commercial sex workers and $86.9 \%$ reported inconsistent use of condoms. Besides; alcohol drinking was reported by $17.2 \%$ of the respondents whereas $4.8 \%$ of the study participants said that they chew khat. Alcohol drinking ( $\mathrm{AOR}=7.77,95 \% \mathrm{CI}=3.04,19.87)$, perception of being at high risk of getting HIV (AOR $=3.97,95 \% \mathrm{CI}=1.08,14.59)$ and younger age status $(\mathrm{AOR}=2.9,95 \% \mathrm{CI}=1.38,6.13)$ were found to be significantly associated with risky sexual behaviors.
\end{abstract}

Conclusion: Above one-third of the respondents had at least one of the risky sexual behaviors. Perception of being at high risk of getting HIV, alcohol drinking, and younger age status were major determinants of risky sexual behaviors.

Keywords: Risky sexual behavior; Students; Mizan-Aman College of Health Science; Ethiopia

Abbreviations: EDHS: Ethiopian Demographic Health Survey; FPC: Finite Population Correction; SPSS: Statistical Package for Social Sciences; STI: Sexually Transmitted Diseases

\section{Introduction}

Risky sexual behavior is a behavior related to sexuality which increases the susceptibility of an individual to reproductive health problems like Sexually Transmitted Diseases (STIs), unwanted pregnancy, abortion and psychological distress. Risky sexual behavior includes having more than one sexual partner, early sexual initiation, inconsistent use of condom, and having sex with commercial sex workers. Additionally, the use of substances during sex may engage young peoples in risky sexual behaviors since it affects their judgment. Alcohol use is cited as one of the common factors which increase the risk of HIV acquisition [1-3]. Adolescents constitute the largest percentage of people in the developing countries, especially in sub-Saharan Africa. Promotion of safe sex and encouragement of contraceptive use would contribute immensely to the reduction in sex-related morbidity and mortality caused by teenage pregnancy, abortion, HIV/AIDS and at the same time reduces the population explosion. To do this however, there is the need to understand their sexual behaviors in order to design effective interventions [4].

Young people face the increased risky sexual behavior by virtue of their social position, unequal life chances, rigid and stereotypical gender roles and poor access to education and health services. Besides, they have limited access to reproductive health 
services that focus on the special needs of adolescents. Inadequate knowledge about adolescents' sexual behavior by the society, cultural influences and the limited capacity of implementing reproductive health services hinder the provision of reproductive health education and services to the young [5]. The behaviors young people adapt and those they maintain throughout their sexual lives will determine the course of epidemic for decades to come. They will continue to learn from one another, but their behavior will depend largely on the information, skills and services that the current generations of adults choose to equip their children with [6]. Therefore, the aim of this study was to assess the prevalence of risky sexual behaviors and associated factors among students of Mizan Aman College of Health Science, Southwest Ethiopia.

\section{Methods and Materials}

\section{Study Area and Period}

This study was conducted on students of Mizan Aman College of Health Science, Southwest Ethiopia, from Sep 15-25/2017. Mizan Aman College of Health Science is one of the government health science colleges in Southern Nations Nationalities and Peoples Regional State of Ethiopia. It was established in 2007. The college is located in Mizan Aman town, 591 KMs Southwest of Addis Ababa. Currently, the college trains students in seven different departments' namely Emergency Medical Technology, Health Extension Worker, Clinical Nursing, Midwifery, Health Information Technician and Medical Laboratory.

\section{Study Design}

A cross sectional study design was conducted.

\section{Inclusion Criteria}

All eligible students were included.

\section{Exclusion Criteria}

Students who were unable to complete the questionnaire were excluded.

\section{Sample Size Determination}

The sample size was determined using single population proportion formula. It was calculated by taking the prevalence rate of sexual intercourse with commercial sex workers among Haromaya University students which was $52.7 \%$ [2]. Five percent margin of error with $95 \%$ confidence of certainty of any outcome was used (where $n_{f}$ is the desired final sample size, $n_{i}$ is the initial sample size, $\mathrm{Z}$ is the value of standard normal variable at $95 \%$ confidence interval, and $\mathrm{P}$ is the prevalence of sexual intercourse with commercial sex workers). For the population size was less than 10,000 finite population corrections (FPC) formula was used to get the final sample size. Therefore, the final sample size with $10 \%$ non-response rate was 331 [6].

\section{Sampling Technique}

The sample size was proportionally allocated for each of the six departments based on the number of students in the departments. Then simple random sampling technique was used to select the study participants.

\section{Data Collection Tool and Procedure}

Structured self-administered questionnaire adapted from EDHS 2016 was used. The questioner was translated in to local languages (Amharic) and vice versa. Data for this study was collected by self-administrative questionnaires. Six BSc holder data collectors and two MSc holder supervisors were participated in the study. Half a day orientation was given to the data collectors and supervisors.

\section{Data Quality Control}

Half a day orientation was given to data collectors and supervisors. Pre-test was conducted on $5 \%$ of the sample before the actual data collection. Daily supervision was held by field supervisors and the investigators.

\section{Data Processing and Analysis}

Data was analyzed using SPSS version 20.0. Data was edited, cleaned, coded and entered using EPI data and then exported in to SPSS for analysis. Bivariate and multivariate logistic regression analysis was done to determine the determinants of risky sexual behavior. P-value $<0.05$ was used to declare statistically significant variables.

\section{Definition of Terms}

Risky Sexual Behavior: refers to at least one of the following; unprotected sex, having multiple sexual partners, starting sex before age of 18 years and sexual intercourse with commercial sex workers in the last 12 months.

Inconsistent Condom use: refers to response option other than always (like rarely, never used and occasionally) about frequency of condom use during sexual contact

Multiple Sexual Partners: having two or more life time sexual partners in the last 12 months.

Substance use: Use of at least any one of the following substances: alcohol, khat cigarette, shisha, or hashish.

HIV Risk Perception: Students' attitude towards perceiving themselves as susceptible to HIV infection.

\section{Comprehensive Knowledge about AIDS}

Defined as knowing that both condom use and limiting sex partners to one uninfected partner are HIV prevention methods, being aware that a healthy-looking person can have HIV, and rejecting the two most common local misconceptions in Ethiopiathat HIV/AIDS can be transmitted through mosquito bites and by supernatural means.

\section{Result}

\section{Socio-Demographic Characteristics}

In this study, a total of 331 study participants had completed the administered questionnaires with a response rate of $100 \%$. 


\section{JOJ Nursing \& Health Care}

The mean age of the study participants was 20.4 years. Majority, Orthodox, 158(47.7\%), was the dominant religion in the study 93(28.1\%), of the study participants were Kaffa in Ethnicity. area (Table 1).

Table 1: Frequency distribution of Socio-demographic characteristics of the students in Mizan Aman Health Science College, Ethiopia, Sep 2017.

\begin{tabular}{|c|c|c|}
\hline Variables & Frequency $(\mathrm{N}=331)$ & Percent \\
\hline \multicolumn{3}{|c|}{ Sex } \\
\hline Male & 69 & 20.8 \\
\hline Female & 262 & 79.2 \\
\hline \multicolumn{3}{|c|}{ Age } \\
\hline$<20$ & 157 & 47.4 \\
\hline $20-24$ & 136 & 41.1 \\
\hline$>25$ & 38 & 11.5 \\
\hline \multicolumn{3}{|c|}{ Ethnicity } \\
\hline Bench & 63 & 19.0 \\
\hline Kafa & 93 & 28.1 \\
\hline Amhara & 49 & 14.8 \\
\hline Oromo & 21 & 6.3 \\
\hline Sheka & 21 & 6.3 \\
\hline Dawro & 24 & 7.3 \\
\hline Gurage & 20 & 6.0 \\
\hline Others & 40 & 12.1 \\
\hline \multicolumn{3}{|c|}{ Religion } \\
\hline Orthodox & 158 & 47.7 \\
\hline Protestant & 134 & 40.5 \\
\hline Muslim & 39 & 11.8 \\
\hline \multicolumn{3}{|c|}{ Marital status } \\
\hline Single & 263 & 79.5 \\
\hline Married & 68 & 20.5 \\
\hline \multicolumn{3}{|c|}{ Educational status of the student } \\
\hline Level 2/year 1 & 79 & 23.9 \\
\hline Level 3/year 2 & 169 & 51.1 \\
\hline Level 4/year 3 & 83 & 25.1 \\
\hline \multicolumn{3}{|c|}{ Department } \\
\hline Health extension & 120 & 36.3 \\
\hline Midwife & 35 & 10.6 \\
\hline Clinical & 72 & 21.8 \\
\hline Laboratory & 52 & 15.7 \\
\hline Health Information Technique & 43 & 13.0 \\
\hline Emergency Medical Technology & 9 & 2.7 \\
\hline \multicolumn{3}{|c|}{ How is education? } \\
\hline Well going & 162 & 48.9 \\
\hline Somewhat good & 137 & 41.4 \\
\hline Not going what i expected & 32 & 9.7 \\
\hline \multicolumn{3}{|c|}{ Income } \\
\hline$<=500$ birr & 138 & 41.7 \\
\hline $501-100$ & 140 & 42.3 \\
\hline$>1000$ & 53 & 16.0 \\
\hline
\end{tabular}


JOJ Nursing \& Health Care

\begin{tabular}{|c|c|c|}
\hline \multicolumn{3}{|c|}{ Living arrangement } \\
\hline With family & 79 & 23.9 \\
\hline Alone & 252 & 76.1 \\
\hline \multicolumn{3}{|c|}{ Father educational status } \\
\hline Not read and write & 75 & 22.7 \\
\hline Read and write & 64 & 19.3 \\
\hline $1-4$ & 38 & 11.5 \\
\hline $5-8$ & 64 & 19.3 \\
\hline $9-12$ & 38 & 11.5 \\
\hline greater than $12^{\text {th }}$ & 52 & 15.7 \\
\hline \multicolumn{3}{|c|}{ Mother educational status } \\
\hline Not read and write & 110 & 33.2 \\
\hline Read and write & 56 & 16.9 \\
\hline $1-4$ & 53 & 16.0 \\
\hline $5-8$ & 60 & 18.1 \\
\hline $9-12$ & 32 & 9.7 \\
\hline Greater than 12 th & 20 & 6.0 \\
\hline \multicolumn{3}{|c|}{ Residence } \\
\hline Urban & 167 & 50.5 \\
\hline Rural & 164 & 49.5 \\
\hline
\end{tabular}

\section{Risky Sexual Behaviours}

About 116 (35\%) had risky sexual behavior. Besides, $122(36.86 \%)$ participants experienced sexual intercourse in their life time whilst $92(75.4 \%)$ of these made sexual intercourse in the last 12 months. Among these, $15(16.3 \%)$ of had more than one partner. Fifty three (57.6\%) of the study subjects had started sexual intercourse before age of eighteen. Among those who make sexual intercourse, seventy two (78.3\%) individuals reported never use condom. Inconsistent condom use was reported by 80 (86.9\%) individuals. The research also revealed that $213(64.5 \%)$ subjects had discussion with family on sexual matters (Figure 1).

\section{risky behavior}

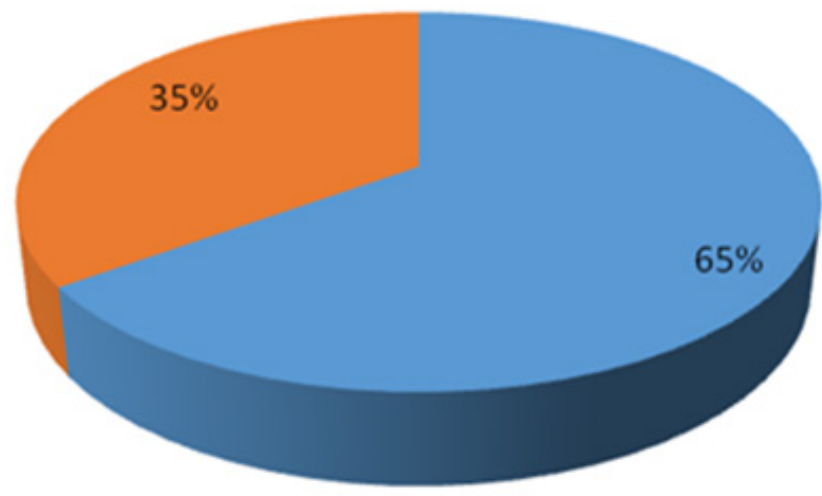

not risky

risky

Figure 1: The proportion of risky sexual behavior of the students in Mizan Aman Health Science College, Ethiopia, Sep 2017.

\section{Knowledge Related Characteristics}

Around 305(92.1\%) of the study participants had heard about HIV/AIDS. Two hundred fifty three (76.4\%) reported that people can reduce their chance of getting HIV/AIDS virus by proper use of condom. Besides, 150(45.3\%) students said both condom utilization and limiting sexual intercourse to one uninfected partner can reduce the risk of acquiring HIV/AIDS. Accordingly, 49 $(14.8 \%)$ of the study participants had comprehensive knowledge of HIV/AIDS (Table 2). 
Table 2: Frequency distribution of knowledge related characteristics among students in Mizan Aman Health Science College, Ethiopia, Sep 2017.

\begin{tabular}{|c|c|c|c|}
\hline Variables & Response & Freq. $(\mathrm{N}=331)$ & $\%$ \\
\hline \multirow{2}{*}{ Have you ever heard of an illness called AIDS? } & Yes & 305 & 92.1 \\
\hline & No & 26 & 7.9 \\
\hline \multirow{2}{*}{$\begin{array}{l}\text { Can people reduce their chances of getting the AIDS virus by having just one uninfected sex } \\
\text { partner who has no other sex partners? }\end{array}$} & Yes & 180 & 54.4 \\
\hline & No & 151 & 45.6 \\
\hline \multirow{2}{*}{ Can people get the AIDS virus from mosquito bites? } & No & 220 & 66.5 \\
\hline & Yes & 111 & 33.5 \\
\hline \multirow{2}{*}{$\begin{array}{l}\text { Can people reduce their chance of getting the AIDS virus by using a condom every time they have } \\
\text { sex? }\end{array}$} & Yes & 253 & 76.4 \\
\hline & No & 78 & 23.6 \\
\hline \multirow{2}{*}{ Can people get the AIDS virus by sharing food with a person who has AIDS? } & Yes & 49 & 14.8 \\
\hline & No & 282 & 85.2 \\
\hline \multirow{2}{*}{ Can people reduce their chance of getting the AIDS virus by abstaining from sexual intercourse? } & Yes & 244 & 73.7 \\
\hline & No & 87 & 26.3 \\
\hline \multirow{2}{*}{ Can people get the AIDS virus because of witchcraft, God's curse, or other supernatural means? } & No & 170 & 51.4 \\
\hline & Yes & 161 & 48.6 \\
\hline \multirow{2}{*}{ Is it possible for a healthy-looking person to have the AIDS virus? } & Yes & 170 & 51.4 \\
\hline & No & 161 & 48.6 \\
\hline \multirow{2}{*}{$\begin{array}{l}\text { Can people get the AIDS virus by sharing sharp materials such as razors/blades or through } \\
\text { injection with non-sterilized needles? }\end{array}$} & Yes & 255 & 77.0 \\
\hline & No & 76 & 23.0 \\
\hline
\end{tabular}

\section{Risky Perception}

About $269(81.3 \%)$ of the study participants claimed that
HIV/AIDS was a series problem in the community. Besides, 179 $(54.1 \%)$ of the study participants perceived that behavioral change can help to prevent HIV/AIDS (Table 3).

Table 3: Frequency distribution of risky perception of the students in Mizan Aman Health Science College, Ethiopia, Sep 2017.

\begin{tabular}{|c|c|c|}
\hline Is HIV/AIDS series & Frequency $(\mathrm{N}=331)$ & $\%$ \\
\hline Yes & 269 & 81.3 \\
\hline No & 43 & 13.0 \\
\hline I don't know & 19 & 5.7 \\
\hline \multicolumn{3}{|c|}{ Chance } \\
\hline No chance & 204 & 61.6 \\
\hline Low chance & 44 & 13.3 \\
\hline Moderate & 13 & 3.9 \\
\hline High & 9 & 2.7 \\
\hline I don't know & 61 & 18.4 \\
\hline \multicolumn{3}{|c|}{ Why low chance } \\
\hline Never have sex & 141 & 56.9 \\
\hline Abstain & 21 & 8.5 \\
\hline Trust partner & 60 & 24.2 \\
\hline No injection unsterile needle & 16 & 6.5 \\
\hline Use condom & 1 & 0.4 \\
\hline No contact HIV pt & 9 & 3.6 \\
\hline \multicolumn{3}{|c|}{ If medium/high why } \\
\hline Sex with HIV pt & 2 & 9.1 \\
\hline No use condom & 13 & 59.1 \\
\hline More than one partner & 2 & 9.1 \\
\hline Sex with CSW & 1 & 4.5 \\
\hline Condom tear & 1 & 4.5 \\
\hline
\end{tabular}


JOJ Nursing \& Health Care

\begin{tabular}{|c|c|c|}
\hline \multicolumn{1}{|c|}{3} & 13.6 \\
\hline Unsterile injection & \multicolumn{1}{|c|}{ Behavior change prevent HIV } & 45.9 \\
\hline No & 152 & 54.1 \\
\hline Yes & 179 & \\
\hline \\
\hline Yes & Your behavioral change & 64.7 \\
\hline No & 214 & 35.3 \\
\hline
\end{tabular}

\section{Substance Abuse by Respondents}

Fifty seven $(17.2 \%)$ of the respondents said that they drank alcohol prior to the data collection period. In addition, 16 (4.8\%) of the respondents said that they chew chat.

\section{Predictors of Risky Sexual Behavior}

Multivariate logistic regression analysis was conducted to identify the predictors of risky sexual behaviors. Accordingly,

perception of being at high risk of getting HIV, alcohol drinking, and younger age status were major determinants of risky sexual behaviors. The study subjects between age of 20-24 were nearly three times $(\mathrm{AOR}=2.9,95 \% \mathrm{CI}=1.38,6.13)$ more likely to be risky for sexual behavior as compared to those who were below 20 years old. Besides, students who drank alcohol were nearly eight times (AOR $=7.77,95 \% \mathrm{CI}=3.04,19.87)$ more likely to be at risk of acquiring HIV/AIDS as compared to those who never drank alcohol (Table 4).

Table 4: Predictors of risky sexual behavior among students of Mizan Aman Health Science College, Ethiopia, Sep 2017.

\begin{tabular}{|c|c|c|}
\hline Variables & COR & AOR \\
\hline \multicolumn{3}{|l|}{ Age } \\
\hline$<20 y r s$ & 1 & 1 \\
\hline $20-24$ & $3.32(1.95,5.66)^{*}$ & $2.91(1.38,6.13)^{*}$ \\
\hline$>25$ & $20.40(8.16,51.01)^{*}$ & $8.72(1.97,38.72)^{*}$ \\
\hline \multicolumn{2}{|c|}{ Mothers educational status } & \\
\hline Not read and write & 1 & 1 \\
\hline Read and write & $0.56(0.28,1.12)$ & $0.25(0.08,0.78)^{*}$ \\
\hline $1-4$ & $0.78(0.40,1.53)$ & $0.81(0.30,2.19)$ \\
\hline $5-8$ & $0.59(0.31,1.16)$ & $0.49(0.17,1.37)$ \\
\hline $9-12$ & $0.19(0.06,0.56)^{*}$ & $0.13(0.03,0.59)^{*}$ \\
\hline$>12$ th & $0.86(0.33,2.27)$ & $0.99(0.26,3.77)$ \\
\hline \multicolumn{2}{|c|}{ Chance of HIV } & \\
\hline Low & 1 & 1 \\
\hline High & $3.55(1.44,8.74)^{*}$ & $3.97(1.08,14.59)^{*}$ \\
\hline \multicolumn{3}{|l|}{ Alcohol } \\
\hline No & 1 & 1 \\
\hline Yes & $2.43(1.36,4.34)^{*}$ & $7.77(3.04,19.87)^{*}$ \\
\hline
\end{tabular}

\section{Discussion}

In this study an attempt was made to assess the proportion of risky sexual behaviors and its associated factors. The study revealed that $35 \%$ of the study participants were engaged in at least one of the risky sexual behaviors. This is consistent with the finding of a study conducted on students in Arbaminch University [7] whilst it is much higher than the study findings from studies conducted in Jiga High School and Haromaya University [1,2]. The difference might be due to the differences in the socio-cultural variations between the communities in the study institutions, but it needs further investigation. The study revealed that among study subjects who experienced sexual intercourse in the last 12 months $16.3 \%$ had sexual intercourse with more than one partner. This result was much lower than studies conducted among students in Pawe Woreda High School and University of Gondar Ethiopia [8,7]. The disparity might be due to differences in the study settings and/or differences in the level of awareness among the communities of the respective institutions. Besides, the study further showed that $87 \%$ used condom inconsistently. This was higher than the finding from a study conducted on University students in Maroua, Cameroon [9]. The difference might still be attributed to the differences in the level of awareness about the benefits of condom utilization and risks of acquiring sexually transmitted infections.

The study showed that study subjects between ages of 20-24 were nearly three times more likely to be risky for sexual behavior 
as compared to those who were below 20 years old. This finding is concordant with the findings of studies conducted in Gondar University, Ethiopia [10]. This could be because of the risk taking behavior among these age groups, resulting in increased risk of involving in sexual practice as the age increases. Besides, students who drank alcohol were nearly eight times more likely to be at risk of acquiring HIV/AIDS as compared to those who never drank alcohol. This finding is in line with the findings from studies conducted in Colombia and Uganda $[11,12]$. This might be due to the nature of alcohol that alters rational decision making ability, decrease inhibitions and increase risk taking behavior of across individuals $[11,12]$.

\section{Conclusion}

Above one-third of the study participants were engaged in at least one of the risky sexual behaviors. Perception of being at high risk of getting HIV, alcohol drinking and younger age status were found to be major determinants of risky sexual behaviors.

\section{Recommendation}

Ministry of Education in collaboration with Federal Ministry of Health should conduct further studies on the predisposing factors of risky sexual behaviors in academic institutions and work hard on strengthening Sexual Health Education in Schools. Mizan-Aman College of Health Science in collaboration with other stakeholders should strongly work on the awareness creation of students about risky sexual behaviors.

\section{Ethical Approval and Consent to Participate}

Ethical approval letter was obtained from department of Public Health, Mizan-Tepi University. The participants were made aware about the purpose of study and oral consents were obtained accordingly. The participants' rights to refuse or withdraw from the study and confidentiality issues were considered.

\section{Authors' Contribution}

NY, ID \& FD took the role from conception to design and developed the proposal, supervised the data collection process, conducted the final analysis and report writing. TE drafted the manuscript. TE and WA critically reviewed and approved the final manuscript.

\section{Acknowledgment}

Our deepest gratitude and appreciation goes to Mizan Aman College of Health Science for supporting the research by supplying materials. We would also like to extend our great appreciations to the data collectors and supervisors.

\section{References}

1. Getachew Mullu Kassa, Degu G, Yitayew M, Misganaw W, Muche M, et al. (2016) Risky Sexual Behaviors and Associated Factors among Jiga High School and Preparatory School Students, Amhara Region, Ethiopia, pp. 4315729.

2. Tariku D, Lemessa O, Nega A (2012) Patterns of sexual risk behavior among undergraduate university students in Haromaya University, Ethiopia: a cross-sectional study. Pan African Medical Journal 12: 33.

3. MJ Trepka, S Kim, V Pekovic, P Zamor, E Velez, et al. (2008) High-risk sexual behavior among students of a minority-serving university in a community with a high HIV/AIDS prevalence. Journal of American College Health 57(1): 77-84.

4. Tekletsadik Me Higher education, higher risks: YWCA-of-EthiopiaSRHR.

5. (2003) UNAIDS, WHO, AIDS epidemic update, Sub-Saharan Africa, pp. 7-14.

6. UNFPA (2002) HIV/AIDS Prevention Guidance for Reproductive Health Professionals in Developing Country Settings. The population council, Inc, p. 6-20.

7. Bikila S, Gemechu K (2015) Assessment of Risky Sexual Behaviors among Arbaminch University Students, Arbaminch Town, SNNPR, Ethiopia 3(2): 1000189.

8. Mulatu A, Tefera B, Tizta T, Muluwas A (2015) Risky Sexual Behavior and Associated Factors among High School Youth in Pawe Woreda Benishangul Gumuz Region. Science Journal of Clinical Medicine 4(4): 67-75.

9. Noubiap, Nansseu JR, Ndoula ST, Wang B, Jingi AM, et al. (2015) Prevalence and correlates of HIV-risky sexual behaviors among students attending the Medical and Social Welfare Center of the University of Maroua, Cameroon. BMC Res Notes 2(8): 635.

10. Shiferaw, Alemu A, Assefa A, Tesfaye B, Gibermedhin E, et al. (2014) Perception of risk of HIV and sexual risk behaviors among University students: implication for planning interventions. BMC Research Notes 19(7): 162.

11. M Lynne Cooper (2002) Alcohol Use and Risky Sexual Behavior among College Students and Youth: Journal of Studies on Alcohol 14: 101-117.

12. Devika M, Emmanuel K, Per Olof Ö, Anette A (2014) Association between Self-Reported Academic Performance and Risky Sexual Behavior among Ugandan University Students- A Cross Sectional Study. Global Journal of Health Science 6(4): 183-195. 
(C) (i) This work is licensed under Creative cC Commons Attribution 4.0 License DOI: 10.19080/JOJNHC.2018.08.555736

\section{Your next submission with Juniper Publishers} will reach you the below assets

- Quality Editorial service

- Swift Peer Review

- Reprints availability

- E-prints Service

- Manuscript Podcast for convenient understanding

- Global attainment for your research

- Manuscript accessibility in different formats

( Pdf, E-pub, Full Text, Audio)

- Unceasing customer service

Track the below URL for one-step submission https://juniperpublishers.com/online-submission.php 